\title{
Evaluation of the Ugandan Government's Communication Strategies of the COVID-19 Pandemic
}

\author{
Ayodeji O. Awobamise 1
}

(iD) 0000-0003-1474-3553

Yosra Jarrar ${ }^{2^{*}}$

(D) 0000-0003-1595-0933

\section{Godswill Okiyi ${ }^{3}$}

(iD) 0000-0001-6062-2045

${ }^{1}$ Kampala International University, UGANDA

${ }^{2}$ American University in Dubai, UNITED ARAB EMIRATES

${ }^{3}$ Nasarrawa State University, NIGERIA

*Corresponding author: yjarrar@aud.edu

Citation: Awobamise, A. O., Jarrar, Y., \& Okiyi, G. (2021). Evaluation of the Ugandan Government's Communication Strategies of the COVID-19 Pandemic. Online Journal of Communication and Media Technologies, 11(1), e2021xx. https://doi.org/10.30935/ojcmt/10824

ARTICLE INFO

Received: 2 Feb 2021

Accepted: 1 Apr 2021

\begin{abstract}
This study focuses on the communication strategies employed by the Ugandan government in addressing the COVID-19 pandemic. The study used a mixed method approach, including interviews, questionnaires and content analysis. A sample size of 400 was drawn for the survey, five community leaders and health workers were interviewed and 270 COVID-19 media reports were used for the content analysis. The findings showed that the government of Uganda did not engage in dialogue at the grassroots level. Secondly, it was found that the media generally reported on the spread of the virus and the number of daily deaths. However, the findings also showed that the media largely supported and complemented the government's efforts. Finally, little or no effort was made to engage with communities before major preventive and protective measures were announced and enforced by the government. It was suggested that grassroots dialogue and community engagement must be carried out before major decisions are made by the government if they are to be effective in the future.
\end{abstract}

Keywords: COVID-19, risk communication, health communication, communication strategy

\section{INTRODUCTION}

Would the world be a better, or even a different, place if the public understood more of the scope and the limitations, findings, and methods of science? The Bodmer Report (1985) attempted to answer this question and suggested that if those in positions of responsibility had a better understanding of what science and technology can achieve, British industries would be even more competitive. A better understanding of science would significantly improve the quality of public decision-making, because decisions made in light of an adequate understanding of issues are likely to be better than decisions made in the absence of such understanding. Public Relations (also known as public affairs especially in civil service) practitioners in scientific institutions by virtue of their positions, are expected to contribute to society by developing relationships with the target publics and fostering an understanding and support to science by helping to align scientific studies with the needs of society (Gruning \& Gruning, 2001, Papadeli, Tsakiridou, \& Mavrikaki 2020; Verma, Stoffová, \& Zoltán, 2018).

The issue of understanding science and the communication of science in order to ensure that the general population makes the right decisions and adheres to instructions is even more important in today's world.

Copyright $\odot \mathbf{2 0 2 1}$ by authors; licensee OJCMT. This article is an open access article distributed under the terms and conditions of the Creative Commons Attribution License (http://creativecommons.org/licenses/by/4.0/). 
The outbreak of the COVID-19 late in 2019 and the resultant economic and social crisis that followed has shone light on the gap between science communication and the effectiveness of such communication in developing countries. Measures have been taken by governments to stem the growth and spread of the virus. However, the problem lies when such communications do not resonate well with the public (Buomprisco, Ricci, Perri, \& De Sio, 2020; Dawe \& Hardie, 2021).

COVID-19 is one of the many identified forms of corona viruses. According to the World Health Organisation, "Coronaviruses are a large group of viruses that can cause illness in animals and humans". In late 2019, China announced the outbreak of a new strain of this virus, called COVID-19. It first broke out in Wuhan, China and quickly spread around the world, with Italy, Spain and the US recording the most cases of confirmed deaths. Presently, there is neither a vaccine nor a confirmed medication, so governments around the world rely mostly on communicating life saving measures to the general public- implementing social distancing guidelines, stay at home and work from home orders, lockdowns in some major cities around the world and a whole lot of other measures. This would be all but impossible if the people do not get the information properly. If communicating these measures is ineffective, then the threat of the virus to people and societies escalates.

This study therefore seeks to assess the communication approaches adopted by the Ugandan government in addressing the issue of COVID-19 and the effectiveness of such approaches in Uganda.

\section{LITERATURE REVIEW}

According to the Public Relations Society of America (PRSA) (2012), public relations is a strategic communication process that builds mutually beneficial relationships between organisations and their publics. To achieve the broad goals of public relations, an open system model of communication is preferred, where there is a two-way communication between an organisation and its publics and where all decisions are influenced by the feedback from the public. In the context of this study, the government of Uganda is the organisation while the general public is the major public this study is concerned with. To ensure proper communication as explained in the definitions of PR, dialogue and community engagement must be carried out by the government.

Dialogue in communication science is not considered a one-way method of disseminating information to the lay public - whilst scientists have facts at hand; the concerned public have the local knowledge, interest and the problem to be solved (Burns, O'Connor, \& Stocklmayer, 2003). Jasinki (2010) explains that it is important to deploy dialogue as a communication strategy because the general public may have a poor understanding of science, which might lead them to misunderstand or misconstrue certain governmental pronouncements if they are not given a chance to seek clarification. Jasinki goes on to explain that the lack of consensus among politicians can also lead to further confusion in the minds of the general public and therefore a dialogue might help them have a clearer understanding of the issues being addressed. This position is supported by the US Center for Disease Control (CDC) (2017) which recommends community engagement as a way to get local communities prepared to tackle pandemics. The CDC recommends three broad non-pharmaceutical interventions, namely; Personal NPIs (everyday preventive actions that protect people from getting or spreading the virus), community NPI (engagement with community leaders to ensure that people limit face-to-face contact during an epidemic of this nature and finally, the environmental NPIs, which ensure that people take care of their environment to make it difficult for the virus to spread - remove germs from surfaces and objects people use amongst others. A number of international protocols emphasised the need to engage with publics in decision-making. According to The Rio Declaration on Environment and Development Principle 10, “... States shall facilitate and encourage public awareness and participation by making information widely available. Effective access to judicial and administrative proceedings, including redress and remedy shall be provided" (UN, 1992).

Dialogue with regards to bringing about public understanding of science could also be referred to as: citizen science, stakeholder engagement or multi-stakeholder dialogue. A continuum of participation that includes provision of information, consultation (seeking public feedback), involvement (the participation of the public in defining an appropriate solution), and finally empowerment is considered more appropriate. Dialoguing with the purpose of bringing about better understanding of science and the issues being discussed 
could take up four trends that include: form of engagement, frequency, timing and content. Consensus conference and citizen panels are some forms of engagement, with the former there is an open dialogue between experts and citizens and the media, while with the latter a select group of citizens under the guidance of an expert formulates questions to be answered at a conference (Einsiedel, 2008). Therefore, this study seeks to answer the following question:

RQ1: What is the effect of dialogue on the public understanding of the dangers of COVID-19 and preventive measures proposed by the government of Uganda?

Cutlip and Center (1942) proposed what they referred to as the 7Cs of effective communication. These are: completeness, conciseness, consideration, concreteness, courtesy, clearness, and correctness. For completeness, communication must convey all facts required by the target group. Conciseness means communicating what you intend to convey in the least possible words - this is both time and cost saving. Consideration means making an attempt to understand your audience, i.e. the audience's point of view, that is to say adjusting your massage to suit the audience's needs. Clarity suggests emphasising a specific objective at a time, while concreteness implies being particular and clear by using facts and figures. Courtesy calls for the sender to be sincere, polite, judicious and not biased, and the last one being correctness implies that there must be no grammatical mistakes; the message must be correct and well-timed.

Whilst institutions in Uganda, particularly government entities are yet to come to terms with the fact that PR in a contemporary society has since become a strategic management role, counterparts in the developed world are already institutionalizing PR as a strategic management position. To most practitioners, public relations has become institutionalized as a messaging activity that aims to project a positive image in media or to sell products, usually through uncouth means, rather than as a management activity that improves relationships among stakeholders and organizations (Grunig, 2010).

The Stockholm Accords affirm that public relations plays a major role in the expansion of a network society and improves relationships with increasingly influential stakeholders, as well as with society at large, it “...develops skills, continually nurture its relationships with customers, investors, communities, governance, active citizen groups, industry alliances, mainstream and digital media and other situational stakeholders." (p. 7)

According to Vaughan and Tinker (2009), effective communication strategies for health risk communication are very important if the public health and safety is to be ensured and protected during a health pandemic such as the COVID-19 outbreak. They explain that the goal of health risk communication should be to reduce the negative effects of an epidemic where possible. The communication must instruct, motivate and inform self-protective behaviour. This appears to be what most governments around the world have done; they have incessantly promoted the idea of increased personal hygiene and social distancing in order to stem the spread of the virus and protect their citizens. However, the effectiveness of such approaches relies heavily on how they are implemented. Uganda is a dynamic, multicultural country and as such a oneshoe-fit-all approach might not be appropriate to achieve the desired objectives. This study therefore examines the communication approaches of the Ugandan government and how effective they have been in passing across the right messages to the public. This leads to the second research question:

$R Q 2:$ Does the message reach the target audience as intended?

For effective communication of science, public relations should integrate aspects of marketing, while maintaining traditional tools like press releases and conferences (Jasinki, 2010). The broadcast media through entertainment is a good way to disseminate information about the harmful effects of drugs and other lifestyle choices and can help audience members make more informed choices. However, the choice of messages and media must correspond to the culture and beliefs of the target groups to enable them comprehend and adopt the conclusions (Lattimore, Baskin, Heiman \& Toth, 2017). This leads to the third research question:

RQ3: Has the media reportage of the COVID-19 crisis been effective in curbing the spread of the virus?

Community engagement is a term often used interchangeably with community involvement or community participation. Community engagement can thus be defined as involving people in an area with local redevelopment. Success in a community can be achieved through a range of approaches and activities, these oscillate from giving people information and asking them for their views; to giving them a direct say in 
Table 1. Computation of sample size and sampling technique

\begin{tabular}{lccc}
\hline No & Category - Qualitative & Sample size & Sampling technique \\
\hline 1 & Human Health Principal Investigators & 22 & Purposive sampling \\
2 & Government spokesperson & 1 & Purposive sampling \\
3 & Community leaders & 10 & Purposive sampling \\
\hline 4 & Category - Quantitative & & \\
5 & Central Uganda & 80 & Simple random sampling \\
6 & Northern Uganda & 80 & Simple random sampling \\
7 & Eastern Uganda & 80 & Simple random sampling \\
8 & Western Uganda & 80 & Simple random sampling \\
\hline & Southern Uganda & 80 & \\
\hline
\end{tabular}

Source: Primary data

decisions or control of future developments. Centers for Disease Control and Prevention (CDC) defined Community engagement as the process of working collaboratively with and through groups of people affiliated by geographic proximity, special interest, or similar situations to address issues affecting the wellbeing of those people.

Community engagement is the blend of science and art. A community can be anything from a geographical location to a community of similar interests or affiliations. It is, therefore, imperative to devise guiding strategies that best fit a target community to be informed, consulted, involved and empowered. For community engagement to be successful, it must encompass strategies and processes that resonate with the target community in which it eventually manifests (Development, 2019).

There are five objectives from which to choose when embarking on a community engagement activity, these were developed by the International Association for Public Participation and include: inform-this involves keeping the public informed through the media. Consult- aims at obtaining public feedback which involves reliance on public responses before a decision is made. Collaboration entails working with the community in formulating solutions, while empowering aims at placing final decision-making in the hands of the public. Community engagement is important in improving health promotion and health research; it improves the consent process and identifies ethical pitfalls as the general public is likely to be more receptive to the research and reap greater benefits from it $(\mathrm{NIH}, 2011)$. The researchers therefore sought to answer the following question:

RQ4: What is the effect of community engagement on the public understanding of the preventive and protective measures put in place by the government of Uganda?

\section{METHODOLOGY}

A mixed research method was adopted for this study. The study seeks to measure the effectiveness of the Ugandan government's communications regarding the COVID-19 pandemic. To achieve this, the following approaches were used:

1. Interviewing key government stakeholders who are actively participating in the fight against COVID-19 in Uganda. They provided information on the approaches used and the rationale for selecting such approaches. The researchers also sought to find out how the government measured the effectiveness of its COVID-19 communication plans and measures.

2. A questionnaire was distributed to participants in 4 geopolitical zones in Uganda (north, central, west and east). The sample size was calculated using Slovenes formula which gave a sample size of 400.80 copies of the questionnaire were distributed to each geopolitical zone. The reason was to be able to ascertain whether other factors like socio-economic, urban/rural habitation, income levels amongst others played a role in the understanding of the government's directives during the COVID-19 pandemic. Administering the questionnaire is expected to help the researchers ascertain the level of understanding of the government directives, which helps confirm the level of effectiveness of the government's communications. 
3. A textual analysis of the president's speeches and updates on the corona virus crisis. The president's media addresses were widely circulated and readily available on major media online platforms where the researchers collected them from. Key terminologies and statements from the president were extracted and respondents were asked if they understood what they meant and how they plan to abide or follow the instructions given there. This was to confirm whether the rhetoric used by authorities and the president was generally understood and effective.

4. Content analysis of media reports on the virus. Through this, inferences can be made from the content of news reports to corroborate messages sent by authorities. Therefore, the researchers looked out for certain features in newspapers coverage.

Content measures

5. The following thematic codes were considered in the analysis of media coverage. Any comments or portrayal that involve any of the following were included in the analysis:

a. Emphasis on the spread and not the progress the government was making in the fight against the pandemic.

b. Emphasis of media reports on the number of deaths and new cases rather than on those that are recovering from the virus.

c. Reports that focus on the negative effect of the government's efforts, rather than on the positive impact.

d. Emphasis on projecting the number of deaths rather than focusing on potential solutions.

e. Emphasis on blaming the government for the spread of the virus.

The news sphere has been dominated by the COVID-19 pandemic, so there was no shortage of reports to examine. However, this study focused on media reports from the first presidential live broadcast on March 18,2020 . It was in this broadcast that the president instituted the first 32-day ban on gatherings of more than 50 people, and the close down of churches, schools and bars. In the period between March $18^{\text {th }}$ and April $4^{\text {th }}$, the Ugandan president made three live broadcasts with new containment measures that were progressively more restricting. Two major stations were used for this analysis- NTV and NBS. The two stations' social media pages and official websites were used for collecting the data. The reason behind choosing NTV and NBS is that they are the two main TV stations in Uganda which broadcast in the local languages and are widely available throughout the country. Between March 18 and April $4^{\text {th }}$, each station broadcast an average of five COVID-19 related news items per day, bringing the total major broadcasts to 90 within the time period under review. Therefore, 270 COVID-19 related broadcast messages were analyzed in this study.

\section{DATA PRESENTATION, ANALYSIS AND INTERPRETATION}

\section{Dialogue and Public Understanding of Mitigating Measures Adopted by the Ugandan Government to Stem the Spread of the COVID-19 Virus}

Most respondents agreed that it was important to be involved in the decision-making process and that the government representative should be willing to engage and dialogue with the communities if they are to be able to build trust. Respondents were asked to rank the level at which they believe dialogue is important to the understanding of health risks and issues in Uganda. A 5-point Likert scale with 1 being not important and 5 being extremely important was administered. When asked what their role should be in the decisionmaking process, $75 \%$ of the respondents preferred that they should be consulted by the government before a final decision is made that might have a deleterious effect on their livelihoods and their standard of living.

In the interview with the presidential spokesperson, he admitted that a very little attempt was made to consult with the public before making these pronouncements, he explained that, "My priority is to disseminate available information; I cannot interact with communities because the funds are really limited." In the president's address of $30^{\text {th }}$ March 2020, when a ban on private vehicles and a 7pm to 6AM curfew was announced, he explained that he wanted to surprise the general public, so people will not make last minute attempts to travel to their villages and increase the risk of spreading the virus. While the motive might be commendable, the fact remains that little or no consultations or dialogues with the community took place before these decisions 
were made. This directly goes against the recommendations of key international organizations on health risk communication. The recommendations explicitly state that the community must participate in the decision making, if a successful mobilization and citizen participation in the fight against such pandemics is to be achieved.

The health workers interviewed expressed willingness in engaging with the community so as to "create awareness about the dangers of the outbreak." However, the reality on ground is that such proper dialogues were not carried out with their communities. They however ensured that all community clinics had posters explaining the COVID-19 pandemic and how to increase chances of not contracting it. The researchers also observed that a majority of these posters in the hospitals were in English and made use of professional language which might not be effective as the majority of the respondents outside Central Uganda are illiterate or semi-illiterate.

The finding is further supported by the results of the analysis of the quantitative data which showed that $80 \%$ of the respondents in Central Uganda felt that the government did well in dialoguing and interacting with them over the COVID-19 outbreak. However, only 15\% in Northern Uganda said they felt like their opinions or needs were taken into consideration when the government was making decisions and pronouncements over the COVID-19 outbreak. 23\% in eastern Uganda, 35\% in western Uganda and 20\% in northern Uganda said they were relatively satisfied with the government's approach to dialogue. This goes to show that the vast majority of respondents do not feel that the government made use of dialogue when making decision regarding the measures taken to combat the spread of the virus. This might explain the reason for some protests in parts of Uganda, where people felt they have been victimized by the government.

We therefore conclude that while dialogue would have played a significant role in ensuring cooperation among the populace, the government of Uganda largely shied away from that. The excuse was the rapid spread of the virus and as such they could not carry out any meaningful dialogue within the little window they had to act. The findings showed that dialogue was not adopted and communication was largely one-way.

\section{Effective Communication of COVID-19 Preventive and Management Measures in Uganda}

Communication is considered effective only when the intended message is what is received by the recipient. It must be complete, concise, concrete, clear and correct for it to be effective (Cutlip \& Center, 1952). To examine the effectiveness of the message communicated to the public by Museveni led government of Uganda, the researchers asked the respondents what they understood by the following terms; 'COVID-19', 'preventive measures', 'the need for lock down', 'the need to social distancing', 'what social distancing meant' and 'the symptoms of COVID-19'.

The findings of this study showed that only $50(12.5 \%)$ respondents knew what COVID-19 was. 300 respondents (75\%) however understood that COVID-19 is "bad" and can be transmitted from one person to another. While about 250 respondents (62.5\%) understood the need for the lockdown. However, the majority of those that said they understood the lockdown and what the government hoped to achieve by restricting movement said they got the information from a third party and not directly from the president's address. The implication is that there is a strong possibility that the information was further broken down by the third party or journalists for proper understanding of the general public. The majority of respondents also said they understand the need to wash hands regularly, but only 35\% said they think taking the temperature of everyone at major locations like markets and shopping malls was important. This also shows a failure in the communication process, as these measures were implemented, but not properly explained to the public. Finally, a surprising number of respondents, $45 \%$ felt the president was instituting a lockdown for political reasons. When asked about their primary source of information on the issue of COVID-19, the majority of the respondents explained that radio played a significant role in interpreting the information shared by the Ministry of Health of Uganda. This makes sense, because the majority of Ugandans do not have access to TV and rely mostly on Radio for their general information.

Some of the interviewed community members stated that the government banned public gatherings to make it difficult for the opposition to campaign for the upcoming elections and that all these added restrictions are an excuse to postpone the elections if possible. Whereas, a government representative in the ministry of health explained that all restrictions pronounced by the president were made based on advice 
Table 2. Results of the content analysis

\begin{tabular}{lccccc}
\hline S/N & Content & NTV & NBS & Total & Total \% \\
\hline 1 & Emphasis on the spread & 73 & 75 & 130 & 72 \\
\hline 2 & Number of deaths & 61 & 56 & 106 & 59.3 \\
\hline 3 & Government's lack of proper response & 40 & 16 & 56 & 31.5 \\
\hline 4 & Blaming the government & 12 & 11 & 23 & 13 \\
\hline
\end{tabular}

from health experts and that the president had no political motivation when making these pronouncement. This shows a mismatch between the intended message and the received message. It can therefore be concluded that the communication was not completely successful, as a lot of the key components of the message were misunderstood and reluctantly followed by the general population.

\section{Media Reportage of the COVID-19 Crisis and the Spread of the Virus}

To achieve this objective, a content analysis of media reportage was carried out and based on the type of report; we could deduce the role the media played in reporting the COVID-19 pandemic. Did the media contribute to increased anxiety and fear, or did they complement the government's effort? are some of the questions this study hoped to answer. Therefore, the researchers looked out for certain features in the media coverage.

The findings of the content analysis showed that the majority (72\%) of the media reports focused more on announcing new cases of COVID-19 cases around the world and in Uganda. But when it comes to blaming the government or trying to accuse the government of inaction, the media houses were mostly cooperative. Only $31.5 \%$ of all media reports made inferences to the government's lack of proper response and only $13 \%$ outrightly blamed the government for the spread of the virus in Uganda. 59.3\% of media reports on COVID19 highlighted the number of deaths caused by the virus.

The reluctance of the media houses to place any blame on the government might be attributed to other factors including fear of retribution or sanctions, which would require a separate study to find out. What can however be deduced is that the media played a complementary role to the government, raising awareness about the need to follow the government sanctions and explaining the need for social isolation and other preventive measure.

Findings of this study were also confirmed by the findings from the questionnaires. The findings showed that over $87 \%$ of the respondents said that the media helped them in understanding what COVID-19 virus is and how dangerous it is not to observe the preventive measures as proposed by the government. There was however a marked difference in media appreciation between regions. Those outside Uganda Central (which has the highest number of post-secondary school degree holders, $65 \%$ of all respondents in Uganda Central had at least a secondary degree) felt that the media could have done better, especially in broadcasting more in local languages. The findings showed that a $75 \%$ of the total respondents $(N=400)$ felt the language used was too complicated and might be confusing for the majority of Ugandans which might have an impact on the understanding and implementing of protective and preventive measures during the pandemic.

\section{Community Engagement, Public Understanding and Adoption of the Preventive and Protective Measures Put in Place by the Government of Uganda}

Community engagement could be referred to as the collaborative process of working with a target community to address issues that impact their well-being. This means that to be effective, engagement must start at the very beginning of any project, so the afflicted persons get to contribute to the research or solution, however, it was discovered that community engagement programs were hardly used in addressing the COVID-19 pandemic, despite the fact that the majority of the preventive and protective measures are expected to have a serious impact on the day -to-day activities of the average Ugandan.

Findings from the study showed that very little or no public awareness and sensitization campaigns were carried out. Community leaders contacted for this study, all confirmed that they were not consulted or engaged in any way or form by the political leaders before decisions were made. Respondents in the geopolitical zones under study were asked for their preferred mode of communication by the government and $65 \%$ stated that they preferred community meetings as a way of disseminating important information to 
their community. This does not come as a big surprise, considering the fact that community and traditional leaders in Uganda are highly respected and in some communities are more respected and trusted than the government. So information from those traditional leaders may carry more weight for community members. The respondents generally agreed that a community engagement system would have been more effective in passing across information to the public.

\section{CONCLUSION AND RECOMMENDATIONS}

This study sought to examine the government of Uganda's response to the COVID-19 pandemic and focused on the period of $18^{\text {th }}$ March 2020 to April 2020. March $18^{\text {th }}$ was the day of the first presidential broadcast concerning the pandemic and it set the tone for the rest of the preventive and protective measures put in place by the government throughout the pandemic period. While not an exhaustive study-since the pandemic and responses to it are still unfolding as at the time of the study- the study sheds light on the communication approach favored by the government and how effective such approach was. Findings showed that the government did not make use of dialogue and public engagement as communication strategies which might explain why people flouted the orders and even protested measures put in place by the government. Proper and effective sensitization was not put in place, and all of the presidential broadcasts were made in English leaving the non-English speaking groups in the country disadvantaged as they had to rely on media interpretation of what the president said.

It is therefore the recommendation of the researchers that for future risk/health communication for any epidemic or pandemic, the government should involve the grassroots in its decision making because they are the most affected population. Secondly, proper sensitization should be carried out prior to enacting measures that might affect the livelihoods of its citizens. Finally, for communication to be effective, the sender and receiver of the message must have a mutual understanding, it is therefore recommended that broadcast and messages related to other and similar health issues should be made in all locally spoken languages, so no group feels left out of the process. In view of this, the researchers are recommending further studies into the role radio, especially local radio stations in Uganda, played during the COVID-19 outbreak. Since radio is a very popular medium in the country and one of the most accessible for people outside the metropolitan areas of the country, there is a need to further study the type of coverage, nature of coverage and how mitigating measures imposed by the government of Uganda were covered on these radio stations.

Author contributions: All authors were involved in concept, design, collection of data, interpretation, writing, and critically revising the article. All authors approve final version of the article.

Funding: The authors received no financial support for the research and/or authorship of this article.

Declaration of interest: Authors declare no competing interest.

Data availability: Data generated or analysed during this study are available from the authors on request.

\section{REFERENCES}

America, P. R. (2012, November 22). About Public Relations. http://www.prsa.org

Borchelt, E. R. (2008). Public Relations in Science. In M. B. Trench, Handbook of Public Communication of Science and Technology (pp. 147-157). Routledge.

Buomprisco, G., Ricci, S., Perri, R., \& De Sio, S. (2021). Health and Telework: New Challenges after COVID-19 Pandemic. European Journal of Environment and Public Health, 5(2), em0073. https://doi.org/10.21601/ejeph/9705

Burns, T., O'Connor, D., \& StockImayer, S. (2003). Science communication: a contemporary definition (pp. 182202). Sage publications. https://doi.org/10.1177/09636625030122004

Carpenter, A., \& Greene, K. (2016). Social Penetration Theory. In R. Berger \& M. E. Roloff (Eds.), The International Encyclopedia of interpersonal Communication (pp. 1-5). John Wiley \& Sons, Inc. https://doi.org/10.1002/9781118540190.wbeic160

Communicationtheory.org. (2018, July 6). Shannon and Weaver model of communication. https://www.communicationtheory.org/shannon-and-weaver-model-of-communication/ 
Dawe, V., \& Hardie, J. (2021). The Rise of the Big Data Doctor: Recent Advances and Warnings in Digital Public Health Technology. Electronic Journal of General Medicine, 18(3), em284. https://doi.org/10.29333/ejgm/9763

du Plessis, H. (2017). Politics of science communication in South Africa. Journal of Science Communication, 16(3), A03. https://doi.org/10.22323/2.16030203

Einsiedel, E. E. (2008). Public Participation and Dialogue. In M. Bucchi \& B. Trench (Eds.), Handbook of Public Communication of Science and Technology (pp. 173-184). Routledge.

Gilaninia, S., Taleghani, M., \& Mohammadi, M. E. (2013). The role of public relations in an organisation. Arabian Jurnal of Business and Management Review (Nigeria Chapter), 47-51. https://doi.org/10.12816/0003699

Griffin, E. (2008). A First Look at Communication Theory. In I. Altman, \& D. Taylor (Eds.), A First Look at Communication Theory (pp. 113-124). McGraw-Hill.

Grinig, J. E., \& Hunt, T. (1984). Managing public relations. Harcourt Brace Jovanovich.

Grunig, J. E. (2011). Public relations and strategic management: Institutionalising organisation-public relationships in contemporary society. Central European Journal of Communication, 11-31.

Grunig, J. E., \& Dozier, D. M. (1992). Excellence in Public Relations and Communication Management. Lawrence Erlbaum Associates, Inc., Publishers.

Grunig, J. E., \& Grunig, L. A. (2002). Implications of the IABC excellence study for PR education. Journal of Communication Management, 7(1), 34-42. https://doi.org/10.1108/13632540310807232

Guide, M. S. (2018, November 21). Seven C's of Effective Communication. https://www.managementstudyguide.com/seven-cs-of-effective-communication.htm

Jasinski, P. A. (2010). Public Relations as a tool of science communication with society. CENIC Magazine. Biological Sciences, 1-10.

Lattimore, D., Baskin, O., Heiman, S. T., \& L. Toth, E. (2009). Public Relations: The Profession and The Practice. McGraw-Hill.

McMillan, J. H., \& Schumacher, S. (2006). Research in Education: Evidence-Based Inquiry. Allyn and Bacon.

Mugwanya, Z., Gumisiriza, G., Tibaasanga, A., Mugwanya, N., \& Muhumuza, J. (2015). Top 10 Facts About Biosafety and Biotechnology in Uganda by 2015. Kampala: Uganda Bioscience Information Centre.

National Institutes of Health. (2011). Principles of Community engagement. NIH.

Ndlovu, H., Joubert, M., \& Boshoff, N. (2016). Public science communication in Africa: views and practices of academics at the National University of Science and Technology in Zimbabwe. Journal of Science Communication, 15(6), A105. https://doi.org/10.22323/2.15060205

Papadeli, E., Tsakiridou, E., \& Mavrikaki, E. (2020). Using stories to engage students in a health education school program about genetic testing. European Journal of Science and Mathematics Education, 8(3), 107114. https://doi.org/10.30935/scimath/9550

Ricketts, A. (2015, March 23). News. https://www.thirdsector.co.uk/actionaid-says-uganda-counterpartapologised-official-spoke-against-gm-crops/communications/article/1339555

Shipman, M. (2014). Public communication from research institutes: Is it science communication or public relations? Journal of Science Communication, 13(3), C01. https://doi.org/10.22323/2.13030301

Skoogh, Y., Cormick, G. M., \& falconi, T. M. (2010, June 15). Stockholm Accords. http://www.wprf2010.se/draftof-the-stockholm-accords/

Sledzik, B. (2008, August 10). the 4 models of public realtions practice how far have you evolved. https://toughsledding.wordpress.com/2008/08/10/the-4-models-of-public-relations-practice-how-farhave-you-evolved/

Springston, J. K., \& Lariscy, R. A. (2005). Public relations effectiveness in public health institutions. Journal of Health and Human Services Administration, 28(2), 218-245.

Statistics, U. B. (2016). National Population and Housing Census 2014. Uganda Bureau of Statistics.

Studies, C. (2018, June 3). Communication Theories. http://www.communicationstudies.com/communicationtheories/social-penetration-theory

The Royal Society. (1985). The Public Understanding of Science. The Royal Society.

Toss, G., \& Jenni, M. (2017). The emergence of modern science in Australia. Journal of Science Communication, 16(3), A01. https://doi.org/10.22323/2.16030201 
Verma, C., Stoffová, V., \& Zoltán, I. (2018). Descriptive Analysis of Viewpoint of Students and Faculty towards Information and Communication Technology in Relation to Gender: A Case Study of Indian Universities. European Journal of Sustainable Development Research, 2(1), 06. https://doi.org/10.20897/ejosdr/74240

Waddington, S. (2015). A critical review of the Four Models of Public Relations and the Excellence Theory in an era of digital communication. In S. Waddington (Ed.), Chartered Public Relations: Lessons from Expert Practitioners (pp. 1-11). Kogan Page, Limited.

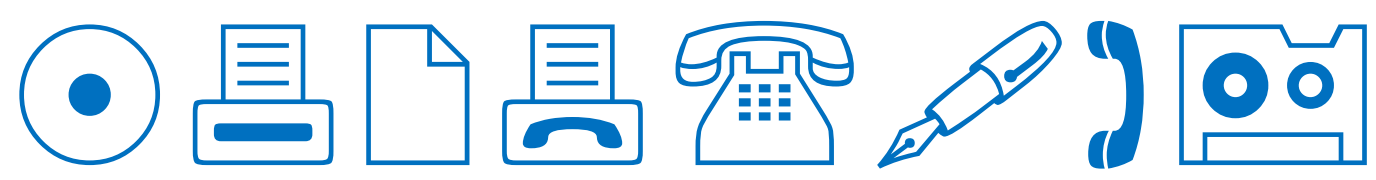

